\title{
SOIL PROFILE CHARACTERISATION OF CHRISTCHURCH CENTRAL BUSINESS DISTRICT STRONG MOTION STATIONS
}

\author{
Liam M. Wotherspoon ${ }^{1}$, Rolando P. Orense ${ }^{2}$, Brendon A. \\ Bradley $^{3}$, Brady R. Cox ${ }^{4}$, Clinton M. Wood ${ }^{5}$ and Russell A. \\ Green $^{6}$
}

(Submitted October 2014; Reviewed February 2015; Accepted June 2015)

\begin{abstract}
This paper presents an overview of the soil profile characteristics at strong motion station (SMS) locations in the Christchurch Central Business District (CBD) based on recently completed geotechnical site investigations. Given the variability of Christchurch soils, detailed investigations were needed in close vicinity to each SMS. In this regard, CPT, SPT and borehole data, and shear wave velocity $\left(V_{s}\right)$ profiles from surface wave dispersion data in close vicinity to the SMSs have been used to develop detailed representative soil profiles at each site and to determine site classes according to the New Zealand standard NZS1170.5. A disparity between the NZS1170.5 site classes based on $V_{s}$ and SPT $N_{60}$ investigation techniques is highlighted, and additional studies are needed to harmonize site classification based on these techniques. The short period mode of vibration of soft deposits above gravels, which are found throughout Christchurch, are compared to the long period mode of vibration of the entire soil profile to bedrock. These two distinct modes of vibration require further investigation to determine their impact on the site response. According to current American and European approaches to seismic site classification, all SMSs were classified as problematic soil sites due to the presence of liquefiable strata, soils which are not directly accounted for by the NZS1170.5 approach.
\end{abstract}

\section{INTRODUCTION}

An extensive database of strong ground motion records has been captured by the strong motion station (SMS) network in the Canterbury region during the 2010-2011 Canterbury earthquake sequence [1-2]. However, in order to comprehensively understand the ground motions recorded at these sites and to be able to relate these motions to other locations, a detailed understanding of the geotechnical profile at each SMS is required. This paper presents updated soil profile classifications of the SMSs in the Christchurch Central Business District (CBD) based on recently completed geotechnical site investigations. Representative soil profiles were developed for each of the four CBD SMSs using cone penetrometer testing (CPT), boreholes and standard penetration testing (SPT), shear wave velocity $\left(V_{s}\right)$ profiling via surface wave methods, and horizontal to vertical spectral ratio $(H / V)$ data performed/obtained in close vicinity to the station location [3]. This data was used to 1) assess the liquefaction potential of each site, which was compared to the surface manifestation and ground motion characteristics recorded during the Darfield and Christchurch earthquakes, and 2) define the NZS1170.5 [4] site classes with more confidence than the previously assumed classifications. To compare to New Zealand practice, sites were also classified using the National Earthquake Hazards Reduction Program (NEHRP) [5] and Eurocode 8 (EC8) guidelines [6] following American and European practice, respectively.

\section{STRONG MOTION NETWORK OVERVIEW}

Prior to the 4 September 2010 Darfield earthquake, the city of Christchurch was instrumented with a large network of strong motion stations (SMSs), with four strong motion stations located in close proximity to the Christchurch Central Business District (CBD). These four stations listed below and shown in Figure 1 [7] are the focus of this paper:

- $\quad$ Christchurch Botanical Gardens (CBGS)

- Christchurch Cathedral College (CCCC)

- Christchurch Hospital (CHHC)

- Christchurch Resthaven (REHS)

The CBGS SMS is located approximately $600 \mathrm{~m}$ west of the western edge of the Christchurch CBD, housed in a wooden building with a shallow concrete pad foundation (approx. $5 \mathrm{x}$ $10 \mathrm{~m}$ ). The CCCC SMS is housed in a two storey concrete walled building with a shallow concrete pad foundation. The footprint of this section of the structure is approximately $10 \mathrm{x}$ $25 \mathrm{~m}$. Additional sections of the structure are connected to this, resulting in a complex structural arrangement. The CHHC SMS was housed in the ground level of a large 2-storey reinforced concrete building with a shallow concrete pad foundation (approx. $25 \times 55 \mathrm{~m}$ ). The REHS SMS is housed in a single-storey timber frame shed with a shallow concrete pad foundation (approx. $2 \times 4 \mathrm{~m}$ ). Summaries of each SMS location and associated strong ground motion records are available from GeoNet [7]. At present, there are five SMSs (CBGS, CCCC, KILS, MORS \& REHS) and a building array

\footnotetext{
${ }^{1}$ Corresponding Author, Senior Lecturer, University of Auckland, Auckland, l.wotherspoon@auckland.ac.nz (Member)

${ }^{2}$ Associate Professor, University of Auckland, Auckland (Member)

3 Associate Professor, University of Canterbury, Christchurch (Member)

${ }^{4}$ Associate Professor, University of Texas, Austin TX

5 Assistant Professor, University of Arkansas, Fayetteville AR

${ }^{6}$ Professor, Virginia Tech, Blacksburg VA
} 
(CPIB) in the Christchurch CBD. The CHHC SMS was removed in 2013 because the building it was housed in was vacated. The KILS and MORS SMS, and the CPIB building array were installed in 2012.

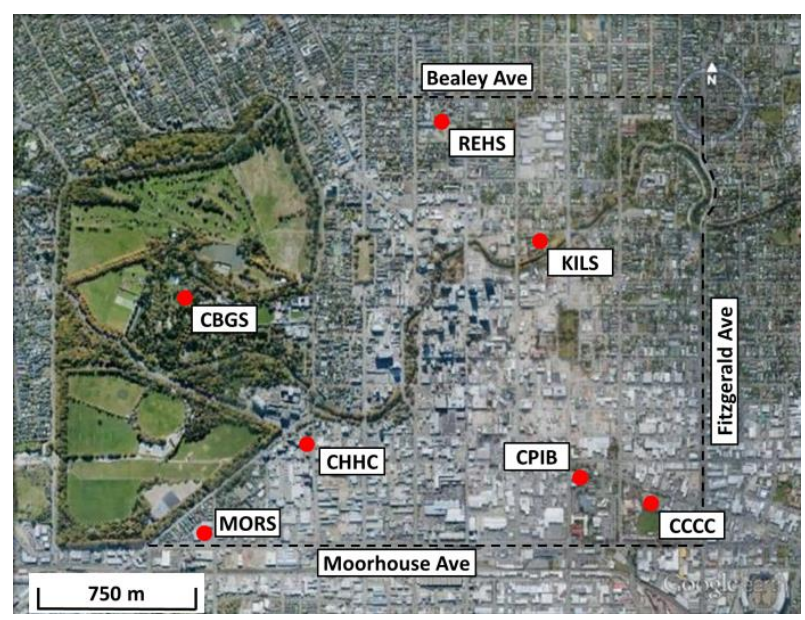

Figure 1: Overview of Christchurch CBD and locations of strong motion stations.

\section{GEOTECHNICAL SITE INVESTIGATION}

\section{Geological Setting}

Away from the Port Hills, the Christchurch CBD is underlain by deep (i.e. many hundreds of metres) sedimentary deposits of interbedded gravels and fine to very fine grain sediments, resulting from episodic glacial and interglacial periods [8] One of the deepest wells in the CBD reaches $150 \mathrm{~m}$ depth, passing through some of these interbedded layers but not encountering rock [9]. Above the Riccarton Gravels, the uppermost of these interbedded gravel layers, the surface sediments are comprised of fluvial gravels, sands and silts comprising the Springston Formation, or estuarine, lagoon, beach, dune, and coastal swamp deposits of sand, silt, clay and peat comprising the Christchurch Formation. There is significant variability in the Springston and Christchurch Formations, both horizontally and vertically, reaching depths of between $20-27 \mathrm{~m}$ in the CBD area. Given the variability in the subsurface conditions in Christchurch, detailed site classifications are needed to accurately characterise the profile at a given location.

\section{Investigation Methodology}

Prior to 2011, no knowledge of the detailed subsurface geotechnical characteristics existed at any of the SMS locations. The soil profiles and site classes were assumed from well logs and regional geology [10]. Therefore, as part of this study CPT, SPT and borehole data, $V_{s}$ profiles, and horizontal to vertical spectral ratio measurements ( $\mathrm{H} / \mathrm{V}$ spectral ratio) performed/obtained in close vicinity to the SMSs were used to develop detailed profiles of the surficial soil layers (to approximately $30 \mathrm{~m}$ depth) at each SMS. Initially, the authors collected existing CPT, borehole and SPT data in the vicinity of each SMS from available sources [11]. At locations with a paucity of data, an additional program of subsurface site investigations was carried out using CPT and borehole methods where appropriate.

Shear wave velocity profiles presented herein were developed using dispersion data from the study summarised in Wood et al. [12] and additional surface wave testing. A combination of active-source and passive-source surface wave techniques were used to resolve the shear stiffness and layering beneath each SMS. Active-source methods included a combination of the Spectral Analysis of Surface Waves (SASW) [13-14] and the Multi-channel Analysis of Surface Waves (MASW) [15], with passive-source testing using 2D microtremor array methods (MAM) [16-17]. The $V_{s}$ profiles for each SMS site were then determined by fitting 3D superposed mode theoretical solutions to the mean experimental dispersion curves using the software WinSASW [18]. The $V_{s}$ profiles presented in this paper are updated versions of the Wood et al. profiles, with layering characteristics from subsurface investigations used to help constrain the layering of the updated shear wave velocity profiles during the inversions. This provides more confidence in the profiles compared to those that were originally developed without any a priori knowledge of the subsurface stratigraphy. Even with these additional depth constraints there will still be some uncertainty in the $V_{s}$ profiles, especially at sites with velocity reversals at depth. Here lower bound estimates have been used in the development of the $V_{s}$ profiles, with subsurface investigation data used to help define the $V_{s}$ of deeper layers.

To determine the site periods, the ratios of the horizontal-tovertical Fourier amplitude spectra (FAS) were computed from ambient noise recordings (i.e., H/V spectral ratios [19]) made at each SMS location using a Nanometrics Trillium Compact 120 second broadband seismometer. At least one hour of ambient noise was recorded at each site and processed using the software Geopsy (www.geopsy.org). The geometric mean of the horizontal components was used to develop the H/V spectral ratios, and a Konno \& Ohmachi [20] smoothing function was applied to the data with a smoothing constant of 40. The $\mathrm{H} / \mathrm{V}$ spectral ratios from a range of time window lengths were compared during processing to determine the influence of window lengths on the estimated spectral peak(s) and to estimate the uncertainty associated with the spectral peak(s). Additional methods used to estimate the site period are summarised in the Site Period section.

\section{SITE CLASSIFICATION METHODOLOGIES}

Three approaches for the definition of site class are presented here: (1) the current New Zealand seismic design standard NZS1170.5 [4]; (2) the National Earthquake Hazards Reduction Program (NEHRP) classifications used in the USA [5]; and (3) Eurocode 8 (EC8) used in Europe [6]. Site classes in these documents are based on undrained shear strength $\left(s_{u}\right)$, SPT $N_{60}$ and/or $V_{s}$, with other additional key factors that are detailed in following sections. Regional geotechnical investigations in Christchurch have shown little change in CPT sounding characteristics before and after major shaking events in the earthquake sequence [21]. Therefore, these site investigations carried out during and following the earthquake sequence can be reasonably assumed to provide a good representation of the pre-sequence soil profile characteristics.

Because the energy efficiency of the SPT hammers used in site investigations were variable (60-99\% based on calibration testing for each drill rig), and in some cases significantly higher than the typical $60 \%$ benchmark, SPT $N_{60}$ values have been used for the NZS1170.5 site classifications in this paper, rather than uncorrected SPT N values.

At each site, CPT data was used to calculate the soil behaviour type index $\left(I_{c}\right)$ as a function of depth, to enable qualitative comparisons with the borehole log data [22]. Because the interpretation of sites classes is based on SPT data for cohesionless soils, CPT data was converted to an equivalent SPT $N_{60}$ value using the correlation from Lunne et al. [23]:

$\frac{\left(q_{t} / p_{a}\right)}{N_{60}}=8.5\left(1-\frac{I_{c}}{4.6}\right)$ 
where $q_{t}$ is the corrected cone resistance, and $p_{a}$ is atmospheric pressure. Wotherspoon et al. [24] investigated the correlation between the estimated and measured $N_{60}$ values using Equation 1 for a database of co-located boreholes and CPT soundings in Christchurch. Figure 2 provides a summary of this comparison, clearly indicating the significant scatter in the data. However, in order to provide some representation of the CPT equivalent SPT blow counts, this correlation has been used herein. When classifying a site according to SPT $N_{60}$ this scatter has been taken into account in order to provide a conservative estimate of the site class.

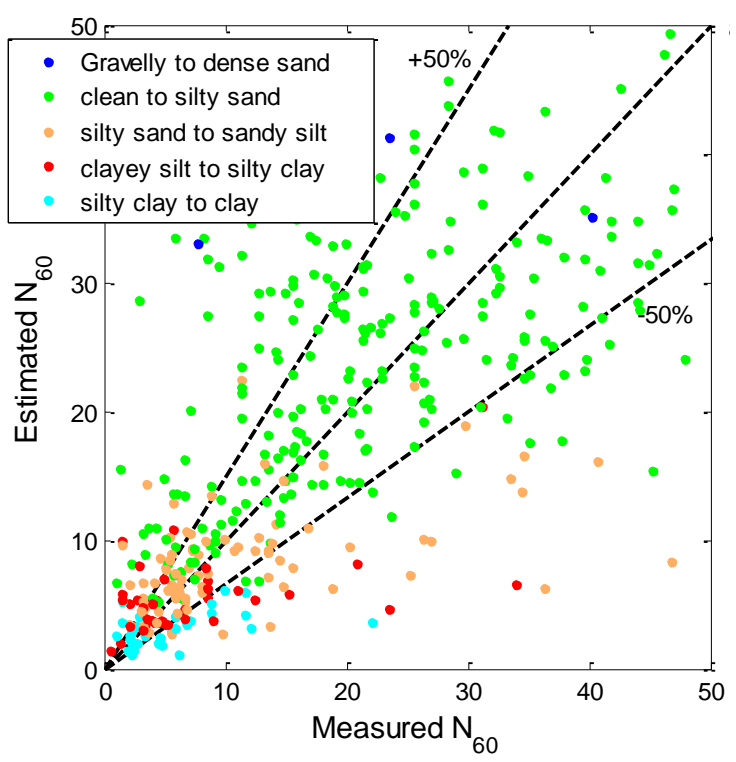

Figure 2: Comparison of estimated and measured SPT $N_{60}$ for Christchurch soils using Equation 1 from Wotherspoon et al. [24].

\section{NZS1170.5 Site Subsoil Classes}

NZ1170.5 uses a combination of $s_{u}$, SPT $N_{60}, V_{s}$, and site period $(T)$ to define site subsoil classes (referred to as site classes in the remainder of this paper). In the Christchurch CBD, all SMS sites have greater than $3 \mathrm{~m}$ of soil above bedrock, which is the cutoff between site class B - rock, and site class C - shallow soil. Therefore, the SMS locations are either site class C - shallow soil, site class D - deep or soft soil, or site class E - very soft soil.

Profiles are site class E if they have greater than $10 \mathrm{~m}$ of low strength material with $s_{u} \leq 12.5 \mathrm{kPa}$, SPT $N_{60} \leq 6 \mathrm{blws} / 0.3 \mathrm{~m}$, or $V_{s} \leq 150 \mathrm{~m} / \mathrm{s}$. Profiles outside these limits are either site class $\mathrm{C}$ or $\mathrm{D}$, and can be differentiated using two approaches. Firstly, if the low amplitude natural period, $T$, (or site period) is less than or equal to 0.6 seconds, the site is classified as site class C. Otherwise, the site is site class D. The natural period of a site can be estimated from (a) a $V_{s}$ profile that extends down to bedrock (or another significant impedance contrast) or (b) direct horizontal-to-vertical spectral ratio (H/V) measurements at the site. For method (a), the natural period of a site is approximated as four times the thickness of the soil deposit over bedrock divided by the average $V_{s}$ of the soil deposit (equivalently stated as four times the shear wave travel time from bedrock to the surface). A comprehensive overview of approaches to define the site period is presented in Larkin \& van Houtte [25]. Secondly, maximum depth limits are defined for site class $\mathrm{C}$ for a range of representative $s_{u}$ and SPT $N_{60}$ soil profiles, but are not summarised herein.

\section{Modified Classification Approach}

In the present study, the choice of the appropriate NZS1170.5 site class at each SMS site has been made based on interpretation and engineering judgment, and not simply by the strict application of site class boundaries. In particular, judgement was used to designate the site class for profiles near the boundary between site classes D and E. Site class E is defined as a site with $10 \mathrm{~m}$ or more of soil with the following characteristics: $s_{u} \leq 12.5 \mathrm{kPa}$, SPT $N_{60} \leq 6$ blws $/ 0.3 \mathrm{~m}$, or $V_{s} \leq$ $150 \mathrm{~m} / \mathrm{s}$. Clearly there are profiles having combinations of depth and soil properties that result in similar site response characteristics, but do not all classify as site class E per NZS1170.5. Therefore, it is proposed that the site class E boundaries be treated as a sliding scale rather than a discrete boundary (e.g., a profile with $12 \mathrm{~m}$ of $180 \mathrm{~m} / \mathrm{s}$ soil or a profile with $8 \mathrm{~m}$ of $120 \mathrm{~m} / \mathrm{s}$ soil should be considered similar to a profile with $10 \mathrm{~m}$ of $150 \mathrm{~m} / \mathrm{s}$ soil in terms of these simplified site classes). In cases where the soil layering does not strictly meet the site class E criteria, but possesses similar site response characteristics, a site classification $\mathrm{E}^{*}$ is proposed for the site. These cases can be broadly defined as follows:

- Profiles with strength/stiffness properties less than the site class E limiting criteria (i.e. $V_{s}<150 \mathrm{~m} / \mathrm{s}$, $N_{60}<6$ ), but where the thickness of these strata are less than the site class $\mathrm{E}$ limit of $10 \mathrm{~m}$. It is proposed that profiles be classified as site class $\mathrm{E}^{*}$ if the combination of reduced strength/stiffness properties and reduced strata thickness would have similar site response characteristics as the site class E limiting criteria. For example, if a soft stratum in a soil profile is only $9 \mathrm{~m}$ thick (i.e., $90 \%$ of the thickness criterion) then the profile would classify as site class $\mathrm{E}^{*}$ if the $V_{s}$ of this stratum is less than or equal to $135 \mathrm{~m} / \mathrm{s}$ (i.e., $0.9 \times 150 \mathrm{~m} / \mathrm{s}=135 \mathrm{~m} / \mathrm{s}$ ). The limiting case for these profiles would be an $8 \mathrm{~m}$ thick stratum with $V_{s} \leq 120 \mathrm{~m} / \mathrm{s}$.

- Profiles with strength/stiffness properties slightly greater than the site class $\mathrm{E}$ limiting criteria (i.e. $V_{s}>$ $150 \mathrm{~m} / \mathrm{s}, N_{60}>6$ ), and where the thickness of these strata are greater than the site class E limit of $10 \mathrm{~m}$. It is proposed that profiles be classified as site class $\mathrm{E}^{*}$ if the combination of increased strength/stiffness properties and increased strata thickness would have similar site response characteristics as the site class E limiting criteria. For example, if a soft stratum in a soil profile has $V_{s}=165 \mathrm{~m} / \mathrm{s}$ (i.e., $110 \%$ of the stiffness criterion) then the profile would classify as site class $\mathrm{E}^{*}$ if the thickness of the stratum is greater than or equal to $11 \mathrm{~m}$ (i.e., $1.10 \times 10 \mathrm{~m}=11 \mathrm{~m}$ ). The limiting case for these profiles would be a $12 \mathrm{~m}$ thick stratum having $150 \mathrm{~m} / \mathrm{s}<V_{s} \leq 180 \mathrm{~m} / \mathrm{s}$.

\section{NEHRP Site Classes}

NEHRP uses either $s_{u}$, SPT $N_{60}$ or $V_{S}$ to define site classes through the calculation of the average of these properties over the top $30 \mathrm{~m}$ of the soil profile. In this paper $V_{S 30}$ was used along with other site investigation data to define NEHRP site classes. The relevant NEHRP site classes for the Christchurch $\mathrm{CBD}$ are site class $\mathrm{C}-360 \mathrm{~m} / \mathrm{s}<V_{S 30} \leq 760 \mathrm{~m} / \mathrm{s}$, site class D $180 \mathrm{~m} / \mathrm{s} \leq V_{S 30} \leq 360 \mathrm{~m} / \mathrm{s}$, site class $\mathrm{E}-V_{S 30}<180 \mathrm{~m} / \mathrm{s}$, and site class $\mathrm{F}$, which are profiles containing soils requiring sitespecific evaluations, including soil profiles with liquefiable layers, or greater than $3 \mathrm{~m}$ of peat and/or highly organic clays. It should be noted that no site specific evaluations of problematic soil types are required by NZS1170.5, with the site class $\mathrm{E}$ property boundaries defined in order to classify sites and soils of this nature [26].

\section{Eurocode 8 Ground Types}

Eurocode 8 uses either $s_{u}$, SPT $N_{60}$ or $V_{S}$ to define ground types (referred to as site classes in the remainder of this paper), with $V_{S 30}$ the preferred method for classification. The 
relevant EC8 site classes for the Christchurch CBD are site class B $-360 \mathrm{~m} / \mathrm{s}<V_{S 30} \leq 800 \mathrm{~m} / \mathrm{s}$, site class $\mathrm{C}-180 \mathrm{~m} / \mathrm{s} \leq$ $V_{S 30} \leq 360 \mathrm{~m} / \mathrm{s}$, and site class D $-V_{S 30}<180 \mathrm{~m} / \mathrm{s}$. A special ground type $S_{2}$ is used to classify soil profiles with potentially liquefiable layers.

\section{SOIL PROFILE SUMMARIES AT CBD STRONG MOTION STATIONS}

A summary of the soil profile characteristics at each SMS is provided in the following sections and in Figures 5-8 in Appendix A. At sites with CPT soundings, $I_{c}$ and CPT equivalent SPT $N_{60}$ values in blow counts per $300 \mathrm{~mm}$ are presented. The $I_{c}$ ranges are defined as follows: $I_{c} \leq 1.31$ : Gravelly sand to sand; $1.31<I_{c} \leq 2.05$ : Clean sand to silty sand; $2.05<I_{c} \leq 2.6$ : Silty sand to sandy silt; $2.6<I_{c} \leq 2.95$ : Clayey silt to silty clay; $2.95<I_{c} \leq 3.6$ : Silty clay to clay; Ic >3.6: Organic material). At sites with boreholes, a summary of the borehole $\log$ and SPT $N_{60}$ values are presented. Although not directly used in site classification, the CPT tip resistance $\left(q_{c}\right)$ is also summarised in each figure. The SPT $N_{60}$ and $V_{S}$ based boundary between site class D and $\mathrm{E}$ is indicated by a dashed vertical line in each figure, with the grey area surrounding this line representing $\pm 20 \%$ of this boundary value. A complete overview of the site investigation data at each SMS is presented in Wotherspoon et al. [3].

\section{Christchurch Botanical Gardens - CBGS}

Borehole, SPT and CPT data, and the $V_{S}$ profile for the CBGS SMS are summarised in Figure 5. The borehole and CPT were a few metres from the SMS, and the $V_{S}$ profile was $20 \mathrm{~m}$ from the SMS. Borehole logs indicate approximately $9 \mathrm{~m}$ of gravels at the surface overlying interbedded layers of sand, sandy silt and silt down to $21 \mathrm{~m}$. $I_{c}$ values also indicate the variability of deposits within the 9-21 m depth range, with the lowest SPT $N_{60}$ values measured in the silt layers. The Riccarton Gravels were encountered at a depth of $21 \mathrm{~m}$, coinciding with a sharp increase in SPT $N_{60}$ values. The CPT sounding also met refusal at this depth. The shear wave velocity profile indicates some soft surface deposits approximately $1 \mathrm{~m}$ thick, underlain by $8 \mathrm{~m}$ of deposits with a $V_{S}$ increasing from 160 to $185 \mathrm{~m} / \mathrm{s}$. Below this the $V_{S}$ reduces from $175 \mathrm{~m} / \mathrm{s}$ to $160 \mathrm{~m} / \mathrm{s}$ in the softer interbedded sands, sandy silts and silts. At a depth of $21 \mathrm{~m}$, there is an increase in the $V_{S}$ to $400 \mathrm{~m} / \mathrm{s}$, correlating with the depth of the Riccarton Gravels at this site. Of note is the significant difference between the $V_{S}$ of the surface gravel and the Riccarton Gravel deposits, clearly indicating the reduced stiffness of the shallow gravel deposits. This marked difference in gravel stiffness is not easily identified through inspection of the SPT data at this location.

\section{Christchurch Cathedral College - CCCC}

CPT data and the $V_{S}$ profile for the CCCC SMS are summarised in Figure 6, with all investigation data less than $50 \mathrm{~m}$ from the SMS. The CPT met refusal at a depth of $25 \mathrm{~m}$, likely coinciding with the depth of the Riccarton Gravels at this site. $I_{c}$ values indicate sands and silty sands between 5 and $15 \mathrm{~m}$, and interbedded layers of sands and silts between 15 and $20 \mathrm{~m}$. From 20 to $25 \mathrm{~m}$, the $I_{c}$ values suggest there is clayey silts and organic materials. Equivalent SPT $N_{60}$ values from the CPT sounding increased from 6 to 50 between 5 and $15 \mathrm{~m}$, and then vary between 6 and 40 through the interbedded sands and silts from 15 to $20 \mathrm{~m}$, with lower values in the silt layers. The 20 to $25 \mathrm{~m}$ layer is much softer, with SPT $N_{60}$ values between 4 and 7 . The geotechnical variability of the wider area surrounding the SMS was also investigated based on three CPT soundings between 160 and $320 \mathrm{~m}$ away from the SMS, and two boreholes/SPT logs that were 240 and $320 \mathrm{~m}$ away from the SMS. All investigations indicate a similar soil profiles and SPT $N_{60}$ values in this area. Based on borehole data from this wider area, the material in the $20-25 \mathrm{~m}$ range is likely sandy silts and organics silts. The Riccarton Gravels were encountered at depths of between 23 and $27 \mathrm{~m}$ at all these locations. The shear wave velocity profile indicates soft surface deposits with a $V_{S}$ less than $130 \mathrm{~m} / \mathrm{s}$ down to a depth of $10.5 \mathrm{~m}$, which is underlain by $9 \mathrm{~m}$ of soil with $V_{S}$ of 220 $\mathrm{m} / \mathrm{s}$. There is a reduction in the $V_{S}$ to $150 \mathrm{~m} / \mathrm{s}$ in the sandy silts/organic silts between 20 and $25 \mathrm{~m}$. Below $25 \mathrm{~m}$ the $V_{S}$ increases to $400 \mathrm{~m} / \mathrm{s}$ in the Riccarton Gravels.

\section{Christchurch Hospital - CHHC}

CPT data, and the $V_{S}$ profile for the CHHC SMS are summarised in Figure 7, with all investigation data less than $30 \mathrm{~m}$ from the SMS. $I_{c}$ values indicate interbedded sands and silty sands to a depth of approximately $8 \mathrm{~m}$, before transitioning into a more clean sand deposit that extends down to a depth of $18 \mathrm{~m}$. From 18 to $22 \mathrm{~m}, I_{c}$ suggests clayey silts and organic materials. These layering and soil characteristics agree well with a borehole log approximately $60 \mathrm{~m}$ from the SMS, with the 18-22 m layer likely low plasticity silts with some organics. The CPT met refusal at a depth of $22.5 \mathrm{~m}$, which was the approximate depth that Riccarton Gravels were encountered in the borehole log. Equivalent SPT $N_{60}$ values from the CPT sounding steadily show a steady increase between 7 and $17.5 \mathrm{~m}$ depth, before dropping sharply in the soft layer above the Riccarton Gravels. The shear wave velocity profile indicates that the $V_{S}$ is $160 \mathrm{~m} / \mathrm{s}$ or less to a depth of $7 \mathrm{~m}$ through the interbedded sands and silts. In the clean sand deposit, the $V_{S}$ increases from 200 to $230 \mathrm{~m} / \mathrm{s}$ to a depth of $17.5 \mathrm{~m}$. The $V_{S}$ then reduces to $150 \mathrm{~m} / \mathrm{s}$ in the soft silt and organic layers, before increasing to $400 \mathrm{~m} / \mathrm{s}$ in the stiff Riccarton Gravels.

Approximately $100 \mathrm{~m}$ north of this location, surface wave testing was performed, which is summarised in Wood et al. [12]. This location was closer to the Avon River, with nearby borehole logs indicating layered deposits of sands and gravels to a depth of between 10 and $15 \mathrm{~m}$. At this location the soil profile was stiffer near the ground surface, with $V_{S}$ in these interbedded layers equal to $185 \mathrm{~m} / \mathrm{s}$. The soft silt and organic layers were then again encountered above the stiff Riccarton Gravel deposits.

\section{Resthaven - REHS}

CPT data and the $V_{S}$ profile for the REHS SMS are summarised in Figure 8, with all investigation data less than $10 \mathrm{~m}$ from the SMS location. One CPT sounding met refusal at a depth of $20 \mathrm{~m}$, likely coinciding with the depth of the Riccarton Gravels at this site. $I_{c}$ values suggest the upper $10 \mathrm{~m}$ consists of a mix of sands, silts, clayey silts and organic material. Equivalent SPT $N_{60}$ values from the CPT soundings throughout the majority of these surface layers are at or below 6. A gravel layer was encountered at approximately $10 \mathrm{~m}$ depth, hence the gap in the CPT record from this depth down to $14 \mathrm{~m}$. Between 14 and $20 \mathrm{~m}, I_{c}$ values suggest sands and silty sands, with equivalent SPT $N_{60}$ values of 40 and above. The geotechnical variability of the wider area surrounding the SMS was also investigated based on five CPT soundings, located between 65 and $150 \mathrm{~m}$ from the SMS, and two boreholes/SPT data, located between 110 and $130 \mathrm{~m}$ from the SMS. All investigations indicate similar soil profiles and SPT $N_{60}$ values in this area. Based on borehole data, the soils down to a depth of $10 \mathrm{~m}$ are a mix of sands, silts and peats, correlating well with that suggested by the $I_{c}$ values. The shear wave velocity profile indicates very soft surface deposits, with $V_{S}$ at or below $95 \mathrm{~m} / \mathrm{s}$ from the surface down to $9 \mathrm{~m}$ depth. The $V_{S}$ increases from $160 \mathrm{~m} / \mathrm{s}$ to $200 \mathrm{~m} / \mathrm{s}$ in the underlying 
gravels and sands down to a depth of $20 \mathrm{~m}$, increasing again to $400 \mathrm{~m} / \mathrm{s}$ below $20 \mathrm{~m}$ in the Riccarton Gravels.

\section{SITE PERIOD}

The site period $(T)$ at each SMS location was estimated using three approaches in this paper. The first approach uses the H/V spectral ratios from ambient noise recordings, as detailed previously. The second approach uses the H/V spectral ratio measurements from strong motion records at each SMS from multiple earthquakes detailed in Wood et al. [12]. The third approach uses the $V_{S}$ profile at each SMS, but because bedrock was not encountered at any of the SMSs, the fundamental period of the material above the base of the $V_{S}$ profile at each location was calculated (equal to $30 \mathrm{~m}$ at each site). Because the Riccarton Gravels created a significant velocity contrast with the overlying looser sediments at each SMS (Christchurch and Springston Formation), the $V_{S}$ profiles were also used to estimate the fundamental period of the soil profile above this gravel layer.

The average $V_{S}$ for the profile $V_{\text {Savg }}$ was calculated using:

$$
V_{\text {Savg }}=\frac{\sum_{i} h_{i}}{\sum_{i} \frac{h_{i}}{V_{s i}}}
$$

where $h_{i}$ is the thickness of layer $i$ and $V_{S i}$ is the shear wave velocity of layer $i$. The fundamental period of this shallow profile ( $\left.T_{\text {shallow }}\right)$ was then defined using:

$$
T_{\text {shallow }}=\frac{4 H}{V_{\text {Savg }}}
$$

where $H$ is the overall thickness of the soil profile (either to the top of the Riccarton Gravels or to $30 \mathrm{~m}$ ).

Table 1 summarises the site period estimates using each of the approaches summarised above, and the $\mathrm{H} / \mathrm{V}$ spectral ratios from ambient noise records at each SMS are summarised in Figure 3. At all sites, the response of the top $30 \mathrm{~m}$ are equal to or in excess of the $T=0.6$ second limit between site class $C$ and $\mathrm{D}$ based on the $V_{S}$ profile approach. The dominant $\mathrm{H} / \mathrm{V}$ spectral peaks from ambient noise recordings generally have a reasonable correlation with the estimated response of the shallow soils above the Riccarton Gravels and with the H/V spectral peaks from the recorded earthquake motions [12]. As mentioned previously, there are many hundreds of metres of soil/gravel overlying bedrock beneath the CBD; therefore this is likely to be a significantly higher mode of vibration that has a much shorter period than the period of the entire soil column down to bedrock. Previous studies have also identified this shallow site period using ambient noise recordings [27-28].

A second, much longer period $\mathrm{H} / \mathrm{V}$ spectral peak was measured from ambient noise at the CCCC and CHHC SMS at $2.4-2.9$ seconds, likely corresponding to the natural period of the deposits above bedrock. There were no clear peaks in this longer period range at any of the other SMS sites; however, there is some evidence of weaker/broader peaks. Christchurchwide studies have shown that it is reasonable to conclude that the site period of the CBD SMS sites (and the CBD as a whole), which are all at least $2.5 \mathrm{~km}$ from the base of the Port Hills, are well in excess of the $\mathrm{T}=0.6$ second limit [29-30].
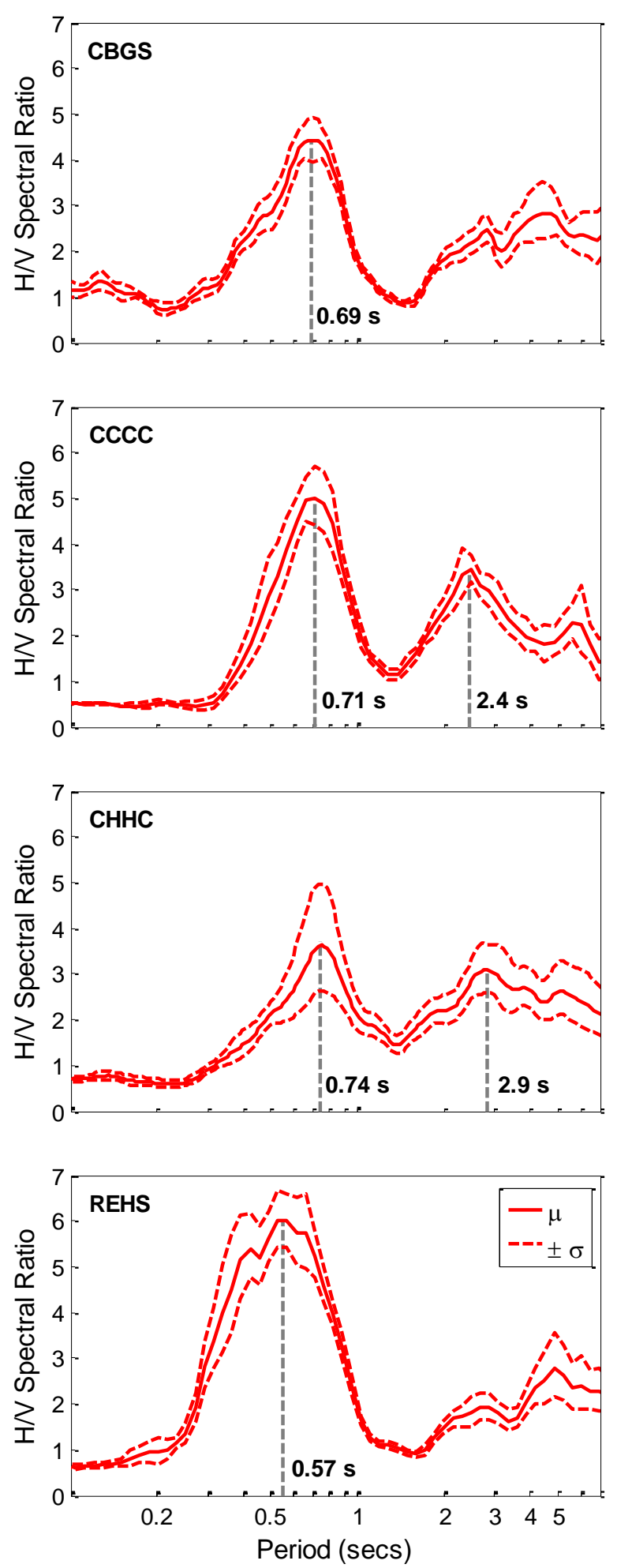

Figure 3: H/V spectral ratio from ambient noise recordings at each CBD SMS. Dashed lines indicate assumed fundamental period of soil deposits above the Riccarton Gravels, with the CCCC and CHHC SMS data showing a second longer period that is assumed to correspond to the site period above bedrock. 
Table 1: Summary of site period estimates and fundamental periods of shallow soil profiles (seconds) at each SMS

\begin{tabular}{|l|c|c|c|c|c|}
\hline \multirow{2}{*}{ SMS ID } & \multicolumn{2}{|c|}{ From $\mathbf{V}_{\mathbf{s}}$ profile } & \multicolumn{2}{c|}{ Ambient noise H/V } & \multirow{2}{*}{ EQ H/V } \\
\cline { 2 - 5 } & $\begin{array}{c}\text { Above } \\
\text { Riccarton } \\
\text { Gravel }\end{array}$ & $\begin{array}{c}\text { Above 30 } \\
\mathbf{m}\end{array}$ & $\begin{array}{c}\text { Short } \\
\text { period }\end{array}$ & $\begin{array}{c}\text { Long } \\
\text { period }\end{array}$ & \\
\hline CBGS & 0.52 & 0.61 & 0.69 & - & 0.45 \\
\hline CCCC & 0.62 & 0.68 & 0.71 & 2.4 & 0.71 \\
\hline CHHC & 0.51 & 0.58 & 0.74 & 2.9 & 0.53 \\
\hline REHS & 0.68 & 0.78 & 0.57 & - & 0.65 \\
\hline
\end{tabular}

The broad short period peak from ambient noise recordings at REHS shown in Figure 3 may be due to the superposition of two peaks, with a small peak to the left of the main peak evident at a period of 0.42 seconds. Using the $V_{S}$ profile, the estimated fundamental period of the very soft surface layers above the shallow gravel at $11 \mathrm{~m}$ depth was equal to 0.42 seconds, providing a good match to this smaller peak. It is also possible that because of this superposition, the main peak is better represented by a slightly longer period, which would provide a better match to the other period estimates at this site.

\section{LIQUEFACTION}

Each SMS site is underlain by at least one liquefiable stratum, as evidenced by the characteristics of the ground motions recorded during the Christchurch earthquake and by liquefaction evaluations performed using subsurface investigation data (Table 2). However, while characteristics of the ground motions at all the sites clearly indicate the occurrence of liquefaction during the Christchurch earthquake, only two sites had surficial liquefaction manifestations in the surrounding area, with the liquefaction features being more than $40 \mathrm{~m}$ away from the SMS at one of these sites. A more complete summary of the assessment of liquefaction at these sites is provided in Wotherspoon et al. [31-32], where the profiles were evaluated by commonly used CPT-based liquefaction assessment procedures (i.e., Robertson \& Wride [22], Moss et al. [33], Idriss \& Boulanger [34]).

Following the 2010 Darfield earthquake, there was no clear surficial manifestation of liquefaction at the ground surface in the immediate area surrounding all CBD SMSs, and the accelerograms from the Darfield earthquake had no clear indication of the occurrence of liquefaction in the underlying soils. However, all liquefaction evaluation procedures were conservative in their assessment, with each predicting the triggering of liquefaction at all the sites [32].

During the 2011 Christchurch earthquake, the recorded motions showed a clear indication of liquefaction of the underlying soils at all CBD SMSs, with characteristic high frequency dilation spikes in the acceleration time histories and reduced high frequency content in the latter part of the records [2]. In these cases, all liquefaction evaluation procedures correctly predicted the triggering of liquefaction [32]. Yet, surficial liquefaction manifestations were not observed at all the SMS sites. First, there was no clear surficial manifestation of liquefaction in the immediate area surrounding the CBGS SMS (Figure 4a), although a few hundred metres to the north of the SMS, significant volumes of ejecta were evident at the ground surface in North Hagley Park. At CCCC, minor volumes of ejecta were evident in the area surrounding the SMS, with a few isolated sand boils approximately $50 \mathrm{~m}$ from the SMS site (Figure 4b). At CHHC, moderate volumes of ejecta in the area immediately adjacent and surrounding the SMS were observed following the Christchurch earthquake
(Figure 4c). Lastly, there was no manifestation of liquefaction at the ground surface in the immediate area surrounding REHS (Figure 4d). A possible reason for the lack of observed surficial manifestations was the presence of competent crust layer that may have prevented the venting of ejecta to the ground surface.

Table 2: Summary of physical indicators of liquefaction at each SMS for the Darfield and Christchurch earthquakes.

\begin{tabular}{|c|c|c|c|c|}
\hline \multirow{2}{*}{$\begin{array}{c}\text { SMS } \\
\text { ID }\end{array}$} & \multicolumn{2}{|c|}{$\begin{array}{c}\text { Severity of surface } \\
\text { manifestation }\end{array}$} & \multicolumn{2}{c|}{$\begin{array}{c}\text { Indicators of } \\
\text { liquefaction in } \\
\text { accelerograms }\end{array}$} \\
\cline { 2 - 5 } & Darfield $^{\mathbf{a}}$ & ChCh $^{\mathbf{b}}$ & Darfield $^{\mathbf{a}}$ & ChCh $^{\mathbf{b}}$ \\
\hline CBGS & $\mathrm{N}$ & $\mathrm{N}$ & $\mathrm{N}$ & $\mathrm{Y}$ \\
\hline CCCC & $\mathrm{N}$ & Minor & $\mathrm{N}$ & $\mathrm{Y}$ \\
\hline CHHC & $\mathrm{N}$ & Moderate & $\mathrm{N}$ & $\mathrm{Y}$ \\
\hline REHS & $\mathrm{N}$ & $\mathrm{N}$ & $\mathrm{N}$ & $\mathrm{Y}$ \\
\hline
\end{tabular}

a 4 September 2010 Darfield earthquake

${ }^{b} 22$ February 2011 Christchurch earthquake

\section{SITE CLASSES}

A summary of the site classes determined using the $V_{S}$ profiles and subsoil geotechnical in-situ test data is presented in Table 3 . The site classes that were originally assumed from well logs and regional geology [10] are also summarised in this table. As detailed in the Site Period section, all SMS locations had a fundamental period to rock greater than 0.6 seconds, putting all locations outside the NZS1170.5 site class C limits. Additionally, the deepest wells in the city are in excess of the $100 \mathrm{~m}$ limiting depth of gravels for site class C [9].

\section{NZS1170.5}

At CBGS approximately $4 \mathrm{~m}$ of soils have SPT $N_{60}<6$, much less than $10 \mathrm{~m}$ limiting thickness for site class E. The $V_{S}$ measurements indicate that there is $12 \mathrm{~m}$ of soil with a $V_{S}$ $\leq 160 \mathrm{~m} / \mathrm{s}$, which is slightly above the site class E limit of $150 \mathrm{~m} / \mathrm{s}$. This does not strictly meet the site class E criteria, but this increased thickness and a velocity within $20 \%$ of the $150 \mathrm{~m} / \mathrm{s}$ boundary suggests that a site class $E^{*}$ may be appropriate. Therefore, using the NZS1170.5 site class definitions, the CBGS SMS site is categorized as site class D based on SPT $N_{60}$ and site class E* based on $V_{S}$.

At CCCC approximately $6.5 \mathrm{~m}$ of soil have SPT $N_{60}<6$, less than the $10 \mathrm{~m}$ limiting thickness for site class E. The $V_{S}$ measurements indicate that there is just over $10 \mathrm{~m}$ of the soil profile with $V_{S}<150 \mathrm{~m} / \mathrm{s}$, less than the site class E cutoff. Therefore, using the NZS1170.5 site class definitions, the CCCC SMS is categorized as site class D based on SPT $N_{60}$ and site class $\mathrm{E}$ based on $V_{S}$. 

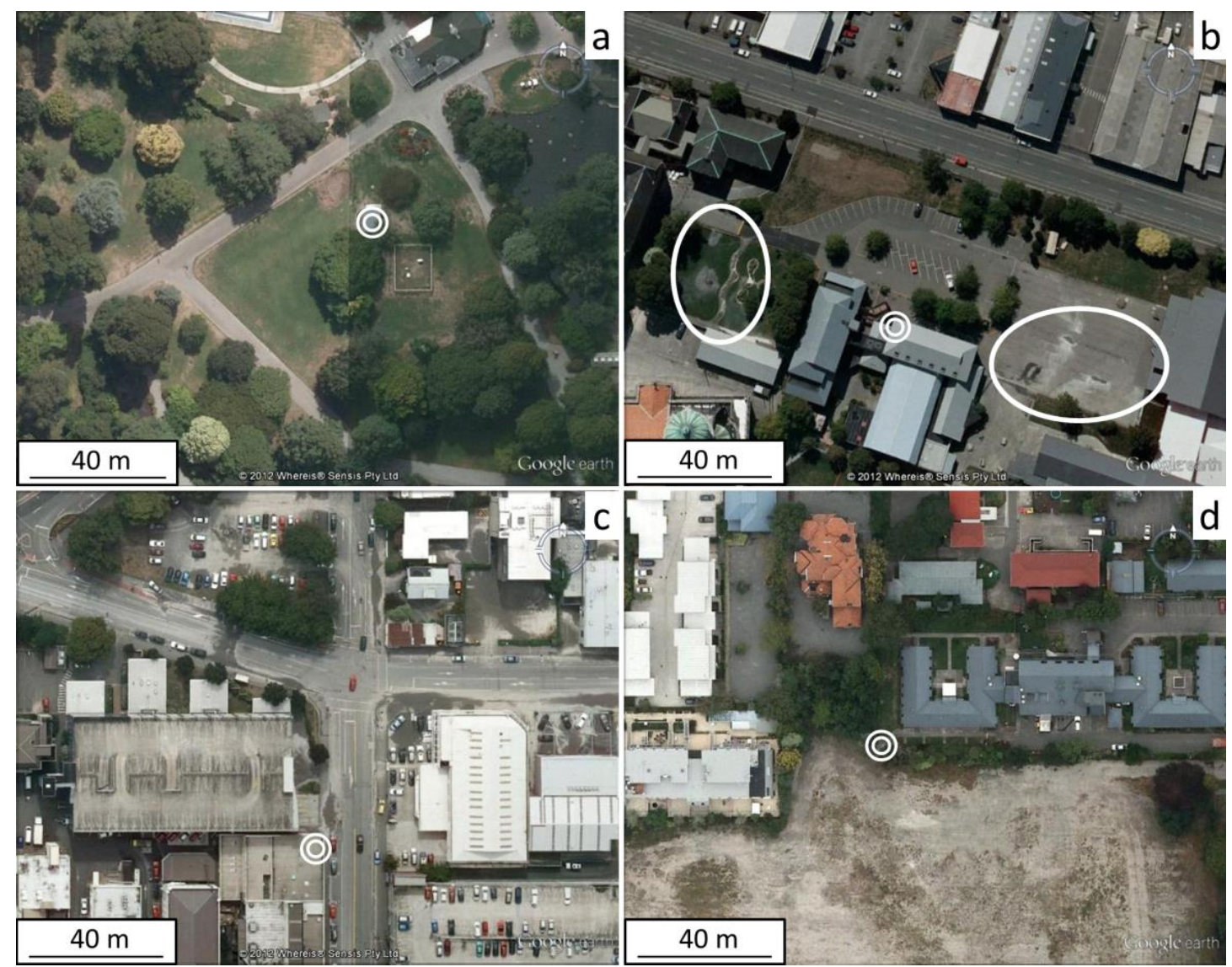

Figure 4: Liquefaction surface manifestation severity following the Christchurch earthquake: a) none - CBGS, b) MinorCCCC, c) Moderate-CHHC, d) none-REHS.

At CHHC approximately $6 \mathrm{~m}$ of soil have SPT $N_{60}<6$, much less than $10 \mathrm{~m}$ limiting thickness for site class $\mathrm{E}$. The $V_{S}$ measurements indicate that there is $6 \mathrm{~m}$ of the soil profile with a $V_{S} \leq 150 \mathrm{~m} / \mathrm{s}$, less than the site class E thickness cutoff of $10 \mathrm{~m}$. However, there is $11.5 \mathrm{~m}$ of soil with $V_{S} \leq 160 \mathrm{~m} / \mathrm{s}$, suggesting that site class $\mathrm{E}^{*}$ may be appropriate. Therefore, using the NZS1170.5 site class definitions, the CHHC SMS is categorized as site class D based on SPT $N_{60}$ and site class E* based on $V_{S}$.

At REHS approximately $8 \mathrm{~m}$ of soils had SPT $N_{60}<6$, which is less than the $10 \mathrm{~m}$ limiting thickness for site class $\mathrm{E}$. This does not strictly meet the site class $\mathrm{E}$ criteria, however of this $8 \mathrm{~m}$, $5 \mathrm{~m}$ have $N_{60}<3$. This is well below the limit for site class $\mathrm{E}$, suggesting that a classification of site class $\mathrm{E}^{*}$ is appropriate. The $V_{S}$ measurements indicate that there is $9 \mathrm{~m}$ of soil with a $V_{S}$ at or below $95 \mathrm{~m} / \mathrm{s}$, well below the $150 \mathrm{~m} / \mathrm{s}$ limit and just less than the site class $\mathrm{E}$ thickness limit of $10 \mathrm{~m}$. This does not strictly meet the site class E criteria, but suggests that a site class $E^{*}$ may be appropriate. Therefore, using the NZS1170.5 site class definitions, the REHS SMS has been categorized as site class E* based on both SPT $N_{60}$ and $V_{S}$.

If the strict definition of site classes were used for both SPT $N_{60}$ and $V_{S}$, CBGS, CHHC, and REHS would all be classified as site class D. However, the site class $E^{*}$ sliding scale has been deemed a more appropriate categorization because it better groups sites having similar site response characteristics. Both SPT and $V_{S}$ based approaches give the same site classification of $\mathrm{E}^{*}$ for the very soft soils at REHS; however, at CBGS, CCCC and CHHC the SPT and $V_{S}$ based approaches give different classifications, with the $V_{S}$ approach indicating a lower site class (site class $\mathrm{E}^{*}$ and $\mathrm{E}$ ). At these locations the SPT $N_{60}$ based classifications were very clearly site class D, with less than $6.5 \mathrm{~m}$ of soil having SPT $N_{60}<6$. The disparity between $V_{S}$ and SPT $N_{60}$ site classifications shown here has also been identified in other studies [35]. Apart from the fact that $V_{S}$ is a small strain property and SPT $N_{60}$ is a strength (large strain) property, another potential issue may arise from correlating SPT $N_{60}$ values from a generic (i.e., non-region specific) CPT relationships, a factor mentioned previously and summarised in Wotherspoon et al [24]. The American Association of State Highway and Transportation Officials (AASHTO) recommend "in all evaluations of site classification, the shear wave velocity should be viewed as the fundamental soil property, as this was used when conducting the original studies defining the site categories" [36]. Clearly the decision to classify a site based on SPT $N_{60}$ versus $V_{S}$ requires further study. But since the response of a site to seismic loading is governed by its shear stiffness, the authors of this paper strongly favour $V_{S}$ classification over SPT $N_{60}$.

CBGS, CCCC and CHHC were all clearly site class D using the SPT $N_{60}$ guidelines, and only CCCC was site class E in strict accord with the $V_{S}$ guidelines in NZS1170.5. CCCC and $\mathrm{CHHC}$ had surficial liquefaction manifestations following the Christchurch earthquake, with CHHC the most severe, and all CBD SMS accelerograms showed characteristics of liquefaction during the Christchurch earthquake. This indicates that the current NZS1170.5 site classification approach may not be able to clearly identify sites that are liquefiable, given that the site class $\mathrm{E}$ property boundaries were defined in order to classify sites and soils of this nature [24]. Additionally, all the sites were predicted to liquefy in both events using currently accepted liquefaction evaluation procedures. A different approach may be necessary to categorize these sites with problematic soils (the same holds true for other problematic soils such as peats/organic clays). 
Table 3: Summary of NZS1170.5 site classes, $V_{S 30}$ and NEHRP and EC8 site classes. In cases where the soil layering does not strictly meet the site class $E$ criteria, but possesses similar site effects potential, a site classification $E^{*}$ has been applied to the site. Letters in brackets indicate the appropriate site class if no liquefiable material was present at these locations.

\begin{tabular}{|c|c|c|c|c|c|c|}
\hline \multirow[t]{2}{*}{ SMS ID } & \multicolumn{3}{|c|}{ NZS1170.5 } & \multirow{2}{*}{$\begin{array}{l}V_{s 30} \\
(\mathrm{~m} / \mathrm{s})\end{array}$} & \multirow[t]{2}{*}{ NEHRP } & \multirow[t]{2}{*}{ EC8 } \\
\hline & $\begin{array}{c}\text { Original } \\
\text { Assumed Site } \\
\text { Class }\end{array}$ & $\begin{array}{c}\text { SPT } N_{60} \\
\text { Site Class }\end{array}$ & $\begin{array}{c}V_{s} \\
\text { Site } \\
\text { Class }\end{array}$ & & & \\
\hline CBGS & D & D & $E^{*}$ & 197 & $F(D)$ & $\mathrm{S}_{2}(\mathrm{C})$ \\
\hline CCCC & D & D & $E$ & 177 & $F(E)$ & $\mathrm{S}_{2}(\mathrm{D})$ \\
\hline $\mathrm{CHHC}$ & $\mathrm{D}$ & D & $E^{*}$ & 206 & $F(D)$ & $\mathrm{S}_{2}(\mathrm{C})$ \\
\hline REHS & D & $E^{*}$ & $E^{\star}$ & 154 & $F(E)$ & $S_{2}(D)$ \\
\hline
\end{tabular}

\section{NEHRP and EC8}

For the NEHRP and EC8 site classes, the letters in parentheses in Table 3 indicate the site class for each profile if no liquefiable material were present. However, because potentially liquefiable layers are present at all the CBD SMS sites, the actual classifications are NEHRP site class $\mathrm{F}$ and EC8 site class $\mathrm{S}_{2}$. Based solely on $V_{S 30}, \mathrm{CBGS}$ and CHHC classify as NEHRP site class D and EC8 site class C because the $V_{S 30}$ values are within the $180-360 \mathrm{~m} / \mathrm{s}$ range. At CCCC and REHS $V_{S 30}$ is less than $180 \mathrm{~m} / \mathrm{s}$, and therefore they classify as EC8 site class D and NEHRP site class E, based solely on $V_{S 30}$.

\section{CONCLUSIONS}

This paper provides a detailed update of the soil profile characteristics at strong motion stations in the Christchurch CBD based on recently completed geotechnical site investigations. These characterization efforts provide a basis for the development of site response analysis models to better understand the observed ground motions in the 2010-2011 Canterbury Earthquake Sequence. At each SMS, NZS1170.5 site classes based on SPT $N_{60}$ and $V_{S}$ did not always agree with the original assumed site classifications, emphasising the importance of having detailed site-specific information at SMS sites in order to properly classify them. To achieve a better delineation between the site classes, the site class $\mathrm{E}$ boundaries were treated as a sliding scale, rather than as a discrete boundary, to account for locations with similar site response characteristics. There was a clear disparity between SPT $N_{60}$ and $V_{S}$ based site classifications at some SMS sites, which is an issue that requires further study, as there is no doubt that $V_{S}$ is a key parameter that directly influences seismic site response.

Because the Riccarton Gravels create a significant velocity contrast with the overlying looser sediments at each SMS, a higher mode of vibration is apparent that has a much shorter period than the period of the entire soil column down to bedrock. Further study is required to determine the impact of the short period mode of vibration of the soft deposits above the Riccarton Gravels, and how to best account for this within the NZ1170.5 site classification framework. Based on the current NZS1170.5 framework all locations in the Christchurch CBD will be either site class D or E.

Using current American and European approaches to geotechnical site classification, all SMSs were classified as problematic soil sites due to the presence of liquefiable strata. Because no site specific evaluations of problematic soil types are required by NZS1170.5, the effect of these soils does not seem to be accounted for by the New Zealand site classification system, with liquefaction occurring in both site class D and E sites.

\section{ACKNOWLEDGMENTS}

Primary support for this research project was provided by Earthquake Commission (EQC) Biennial Grant 12/629. L. Wotherspoon's position at the University of Auckland was funded by the EQC. Primary support for the US authors was provided by the U.S. National Science Foundation (NSF) grant CMMI-1306261, CMMI-1407428, and CMMI-1435494. However, any opinions, findings, and conclusions or recommendations expressed in this material are those of the authors and do not necessarily reflect the views of the NSF. We acknowledge the Canterbury Geotechnical Database for some of the site investigation data used in this study. EQC, CERA, their data suppliers and their engineers, Tonkin \& Taylor, have no liability to any user of this data or for the consequences of any person relying on them in any way. We acknowledge the New Zealand GeoNet project (www.geonet.org.nz) and its sponsors EQC, GNS Science and LINZ, for providing accelerograms used in this study. We also thank the land owners at all SMSs for their cooperation during this study, and the support of McMillan's Drilling.

\section{REFERENCES}

1 Bradley BA and Cubrinovski C (2011). "Near-source strong ground motions observed in the 22 February 2011 Christchurch earthquake". Seismological Research Letters, 82(6): 853-865.

2 Bradley BA (2012). "Strong ground motion characteristics observed in the 4 September 2010 Darfield, New Zealand earthquake". Soil Dynamics and Earthquake Engineering, 42: $32-46$

3 Wotherspoon LM, Orense RP, Bradley BA, Cox BR, Wood CM and Green RA (2014). "Geotechnical characterisation of Christchurch strong motion stations". Earthquake Commission Biennial Grant Report, Project No. $12 / 629$.

4 Standards New Zealand. (2004). "NZS1170.5: Structural Design Actions-Part 5: Earthquake Actions". Standards New Zealand, Wellington, NZ.

5 Building Seismic Safety Council (2003). "NEHRP Recommended Provisions for Seismic Regulations for New Buildings and other Structures, Part1: Provisions". FEMA 450, Federal Emergency Management Agency, Washington, D.C.

6 CEN, European Committee for Standardisation (2003). "Eurocode 8: Design Provisions for Earthquake 
Resistance of Structures, Part 1.1: General rules, seismic actions and rules for buildings". PrEN1998-1.

7 GNS Science (2014). GeoNet. http://www.geonet.org.nz. (accessed June 15, 2014).

8 Brown LJ and Weeber JH (1992). "Geology of the Christchurch urban area". Institute of Geological and Nuclear Sciences, Lower Hutt.

9 Brown LJ and Wilson DD (1988). "Stratigraphy of the late Quaternary deposits of the northern Canterbury plains, New Zealand". New Zealand Journal of Geology and Geophysics, 31: 305-335.

10 Cousins J and McVerry G (2010). "Overview of strong motion data from the Darfield Earthquake". Bulletin of the New Zealand Society for Earthquake Engineering, 43(4): 222-227.

11 Canterbury Earthquake Recovery Authority (CERA) (2012). Geotechnical database for Canterbury earthquake sequence.

https://canterburygeotechincaldatabase.projectorbit.com. (accessed June 15, 2014).

12 Wood CM, Cox BR, Wotherspoon LM and Green RA (2011). "Dynamic site characterization of Christchurch strong motion stations". Bulletin of the New Zealand Society for Earthquake Engineering, 44(4): 195-204.

13 Nazarian S and Stokoe II KH (1984). "In situ shear wave velocities from spectral analysis of surface wave tests". Proc. Eighth World Conference on Earthquake Engineering, San Francisco, California, 31-38.

14 Stokoe II KH, Wright SG, Bay JA and Roesset JM (1994). "Characterization of geotechnical sites by SASW method". Proc. 13th International Conference on Soil Mechanics and Foundation Engineering, New Delhi, India, 923-930.

15 Park CB, Miller RD and Xia J (1999). "Multichannel analysis of surface waves" Geophysics, 64: 800-880.

16 Tokimatsu K, Shinzawa K, and Kuwayama S (1992). "Use of short-period microtremors for Vs profiling". Journal of Geotechnical Engineering, 118(10): 1544-1558.

17 Okada H (2003). "The Microtremor Survey Method". Geophysical Monograph Series no. 12. Society of Exploration Geophysicists,: 135 pp.

18 Joh SH (1996). "Advances in interpretation and analysis techniques for spectral-analysis-of-surface-waves (SASW) measurements". Ph.D. Dissertation, Dept. of Civil, Architectural, and Environmental Engineering, University of Texas, Austin, TX, $240 \mathrm{p}$.

19 Nakamura Y (1989). "A Method for Dynamic Characteristics Estimation of Subsurface Using Microtremor on the Ground Surface". Quarterly Report of the Railway Technical Research Institute, 30(1): 25-33.

20 Konno K and Ohmachi T (1998). "Ground-motion characteristics estimated from spectral ratio between horizontal and vertical components of microtremor". Bulletin of the Seismological Society of America, 88(1): 228-241.

21 Orense RP, Pender MJ and Wotherspoon LM (2011). "Analysis of soil liquefaction during recent Canterbury (New Zealand) earthquakes". Geotechnical Engineering Journal SEAGS \& AGSSEA, 42(3): 8-17.

22 Robertson PK and Wride CE (1998). "Evaluating cyclic liquefaction potential using the cone penetration test". Canadian Geotechnical Journal, 35: 442-459.
23 Lunne T, Robertson PK and Powell JJM (1997). "Cone Penetration Testing in Geotechnical Engineering Practice". Blackie Academic and Professional, New York.

24 Wotherspoon LM, Li Z and Haycock I (2015). "Assessment of SPT-CPT correlations using Canterbury site investigation database". 12th Australia New Zealand Conference on Geomechanics, February 22-25, Wellington, New Zealand

25 Larkin T and van Houtte C (2014). "Determination of site period for NZS1 170.5: 2004". Bulletin of the New Zealand Society for Earthquake Engineering, 47(1): 28-40.

26 Standards New Zealand. (2004b). "NZS1170.5: Structural Design Actions-Part 5: Earthquake ActionsCommentary”. Standards New Zealand, Wellington, NZ.

27 Toshinawa T, Taber JJ and Berrill JB (1997). "Distribution of ground-motion intensity inferred from questionnaire survey, earthquake recordings, and microtremor measurements - A case study in Christchurch, New Zealand, during the 1994 Arthurs Pass earthquake". Bulletin of the Seismological Society of America, 87(2): 356-369.

28 Mucciarelli M (2011). “Ambient noise measurements following the 2011 Christchurch earthquake: Relationships with previous microzonation studies, liquefaction, and nonlinearity". Seismological Research Letters, 82(6): 919926.

29 Wotherspoon LM, Orense RP, Bradley BA, Cox BR, Green RA and Wood CM (2014). "Soil profile characterization of Christchurch strong motion stations". 10th US National Conference on Earthquake Engineering, 21-25 July, Anchorage, Alaska.

30 Wotherspoon LM, Bradley BA, Thomson EM, Hills AJ, Jeong S, Wood CM and Cox BR (2015). "Development of deep Vs profiles and site periods for the Canterbury region". NZSEE Annual Technical Conference, April 1012, Rotorua, New Zealand.

31 Wotherspoon LM, Orense RP, Green RA, Bradley BA, Cox BR and Wood CM (2013). "Analysis of liquefaction characteristics at Christchurch strong motion stations" in Soil Liquefaction during Recent Large-Scale Earthquakes. CRC Press, Leiden, The Netherlands, 33-44.

32 Wotherspoon LM, Orense RP, Green RA, Bradley BA, Cox BR and Wood CM (2015). "Assessment of liquefaction evaluation procedures and surficial manifestation severity at Christchurch strong motion stations". Soil Dynamics and Earthquake Engineering, doi:10.1016/j.soildyn.2015.03.022.

33 Moss RES, Seed RB, Kayen RE, Stewart JP, Der Kiureghian A, and Cetin KO (2006). "CPT-based probabilistic and deterministic assessment of in situ seismic soil liquefaction potential". Journal of Geotechnical and Geoenvironmental Engineering, 132(8): 1032-1051.

34 Idriss IM and Boulanger RW (2008). "Soil liquefaction during earthquakes. Monograph MNO-12". Earthquake Engineering Research Institute, Oakland, CA, 261 pp.

35 Nasseri-Moghaddam A, Bennett J and Polan B (2010). "Seismic site class determination using multichannel analysis of surface waves (MASW)". 9th US National and 10th Canadian Conference on Earthquake Engineering, 25-29 July, Toronto, Canada.

36 American Association of State Highway and Transportation Officials (2011). "Guide Specifications for LRFD Seismic Bridge Design". 2nd Edition, Washington, DC. 


\section{APPENDIX A: CHRISTCHURCH CENTRAL BUSINESS DISTRICT SOIL PROFILE CHARACTERISTICS}

The SPT $N_{60}$ and $V_{S}$ based boundary between site class $\mathrm{D}$ and $\mathrm{E}$ is indicated by a dashed vertical line in each figure, with the grey area surrounding this line representing $\pm 20 \%$ of this boundary value.

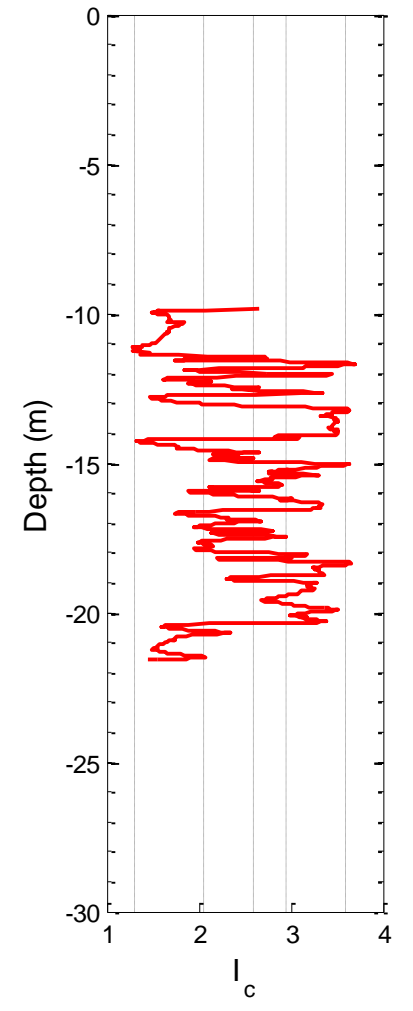

(a)

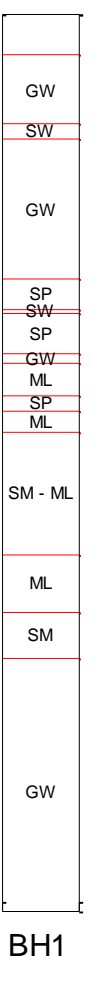

(b)

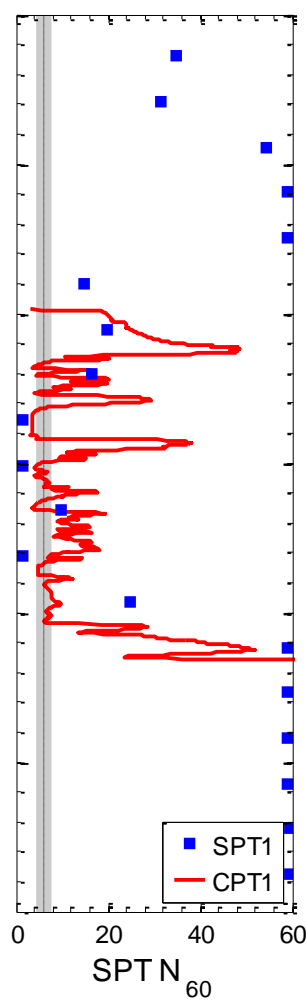

(c)

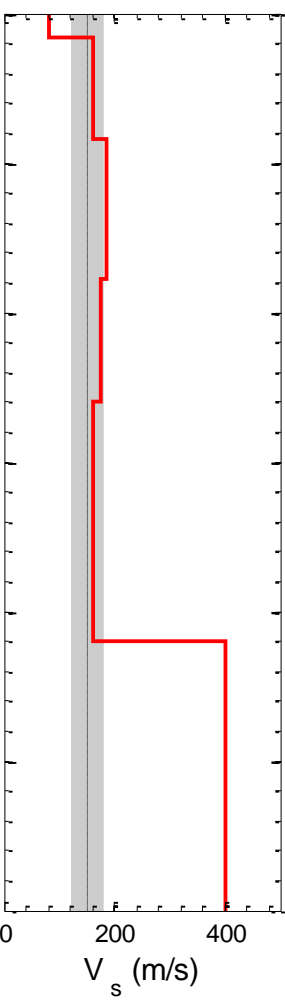

(d)

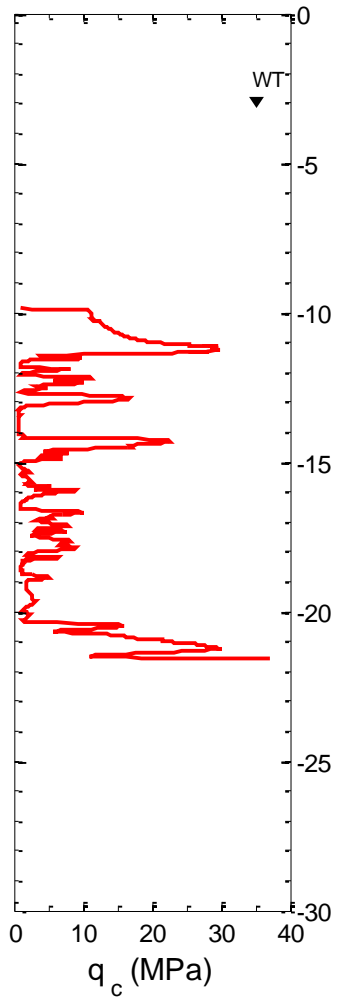

(e)

Figure 5: CBGS geotechnical site investigation summary. a) Soil behaviour type index, b) borehole BH1 log, c) SPT and CPT equivalent blow counts, $d$ ) Shear wave velocity, e) CPT tip resistance.

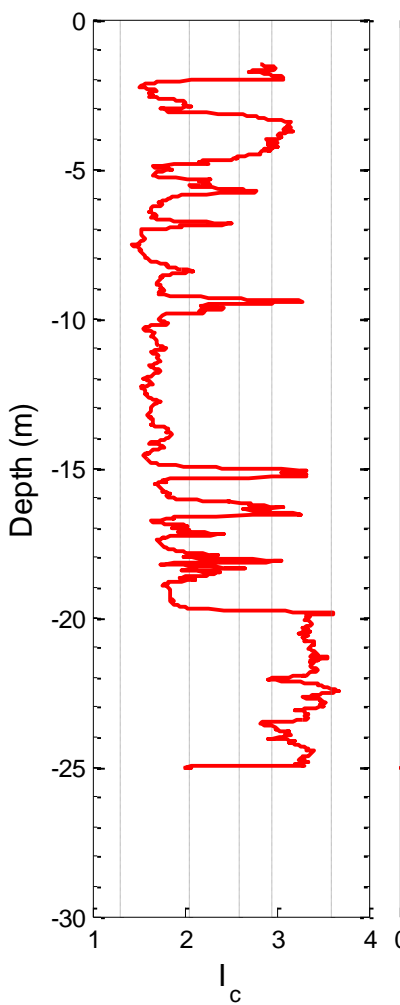

(a)

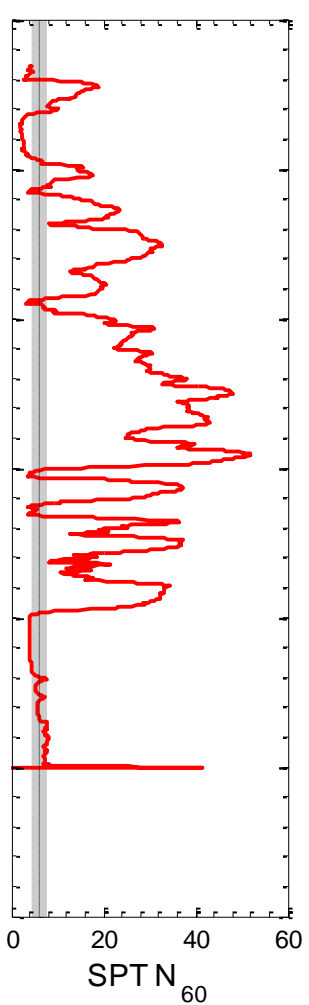

(b)

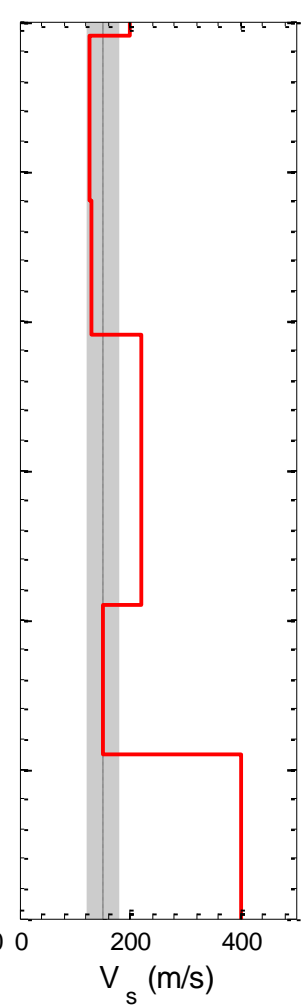

(c)

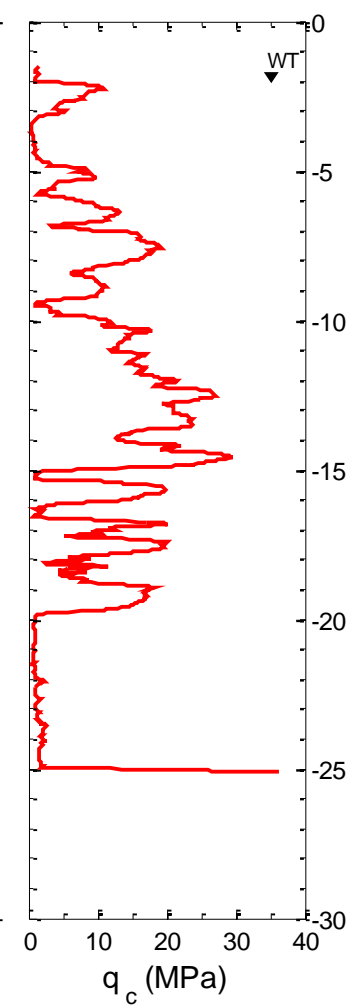

(d)

Figure 6: CCCC geotechnical site investigation summary. a) Soil behaviour type index, b) CPT equivalent blow counts, c) Shear wave velocity, $d)$ CPT tip resistance. 


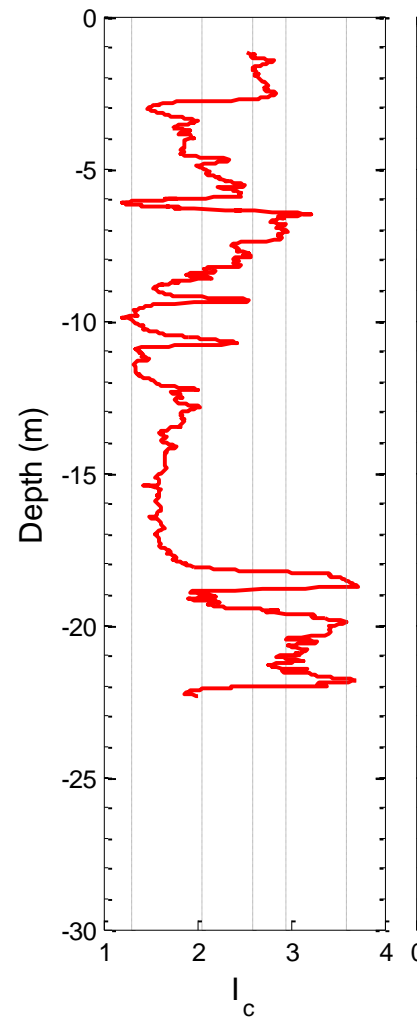

(a)

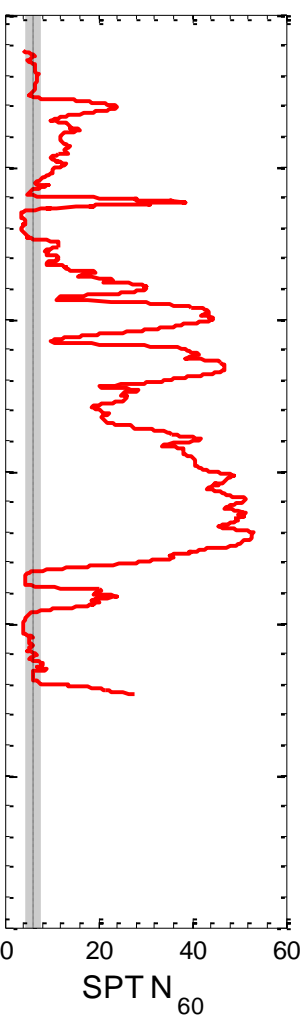

(b)

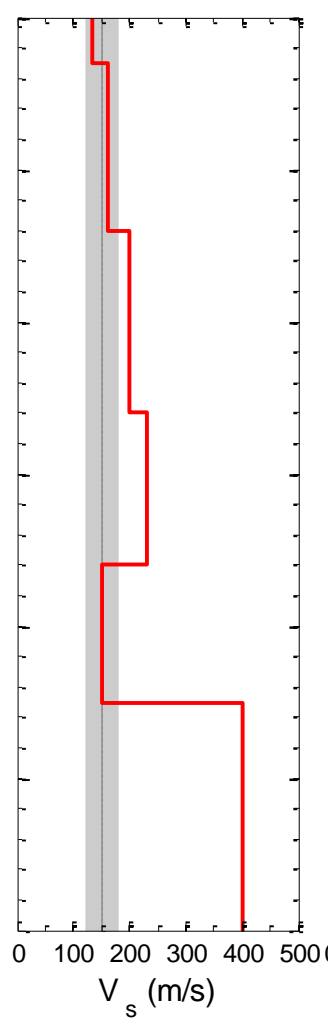

(c)

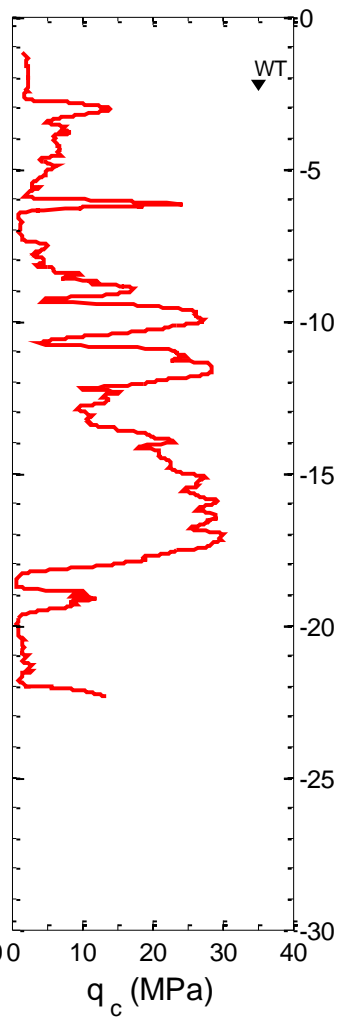

(d)

Figure 7: CHHC geotechnical site investigation summary. a) Soil behaviour type index, b) CPT equivalent blow counts, c) Shear wave velocity, d) CPT tip resistance.

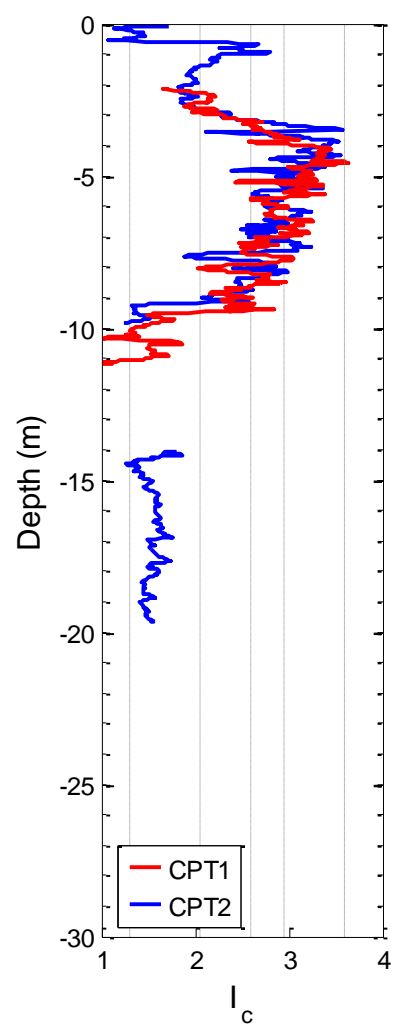

(a)

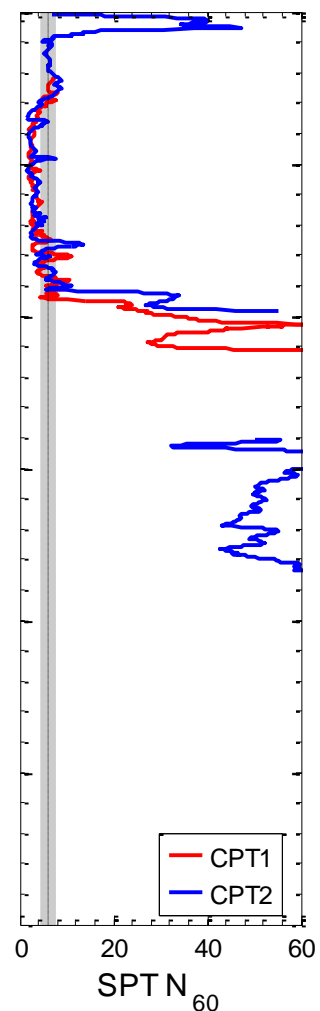

(b)

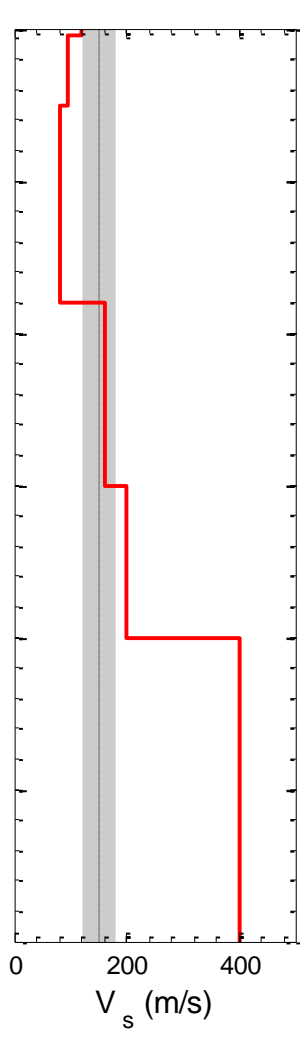

(c)

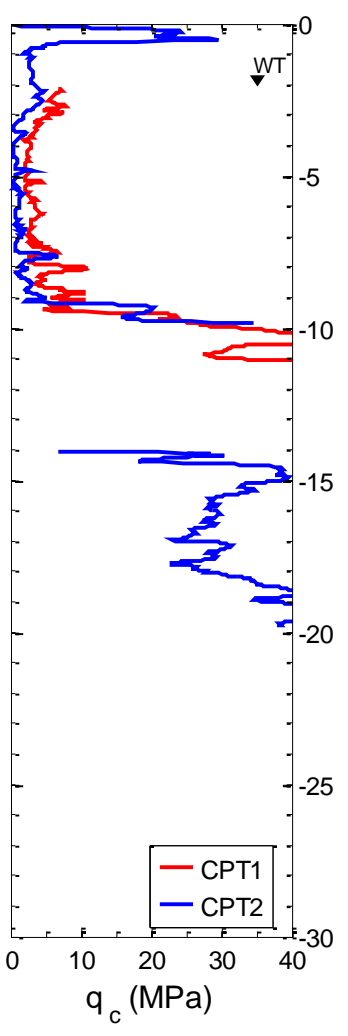

(d)

Figure 8: REHS geotechnical site investigation summary. a) Soil behaviour type index, b) CPT equivalent blow counts, c) Shear wave velocity, d) CPT tip resistance. 